\title{
Cost Analysis of Corn Cultivation in the Setup of the Crop-Livestock-Forest Integration System to Recover Degraded Pastures
}

\author{
Carlos Augusto Rocha de Moraes Rego ${ }^{1}$, Victor Roberto Ribeiro Reis ${ }^{1}$, Alcido Elenor Wander ${ }^{2}$, \\ Ilka South de Lima Cantanhêde ${ }^{3}$, Joaquim Bezerra Costa ${ }^{2}$, Luciano Cavalcante Muniz ${ }^{1}$, Bruna Penha Costa ${ }^{1}$ \\ \& Juan López de Herrera ${ }^{4}$ \\ ${ }^{1}$ Maranhão State University (UEMA), São Luís, Brazil \\ ${ }^{2}$ Brazilian Agricultural Research Corporation (EMBRAPA), Brasília, Brazil \\ ${ }^{3}$ Federal Institute of Education, Science and Technology of Maranhão (IFMA), São Luís, Brazil \\ ${ }^{4}$ Technical University of Madrid (UPM), Madrid, Spain \\ Corresponding author: Carlos Augusto Rocha de Moraes Rego, Maranhão State University (UEMA), São Luís, \\ Brazil. Tel: 55-98-98747-1864. E-mail: cassielcarlos@hotmail.com
}

Received: March 28, $2017 \quad$ Accepted: April 25, $2017 \quad$ Online Published: May 15, 2017

doi:10.5539/jas.v9n6p168 URL: https://doi.org/10.5539/jas.v9n6p168

\begin{abstract}
The objective of this study is to estimate the production costs and profitability of corn cultivation in the setup phase of the crop-livestock-forest integration system for pasture recovery in the municipality of Pindaré-Mirim/MA, Brazil. The study was developed at the Technological Reference Unit (TRU) for the Integration of Crop-Livestock-Forest (ICLF) of Embrapa Cocais, located in the municipality of Pindaré-Mirim/MA, Brazil. Data collection occurred during the agricultural year 2015/2016. The management of the ICLF system was carried out following the molds of the "Santa Fé" technique. The cost of production was used to calculate the Total Operational Cost (TOC) and were extrapolated per hectare. For the economic analysis of corn production, three different prices were considered: (a) the price received by the producer; (b) the historical average of the last 30 months to the date of actual sale of the product; and (c) the minimum guarantee price of the federal government. The TOC was found to be US\$1,672.72 per hectare. The economic efficiency indicators showed promising profit values, demonstrating that in this study with corn production in the 1st year, it would be possible to pay for the implementation of the ICLF system as an alternative for the recovery of degraded pasture.
\end{abstract}

Keywords: economic analysis, integrated production system, lucrativeness

\section{Introduction}

The current specialized production systems, based on monocultures, have been increasingly inefficient regarding yields, making it more difficult to develop new systems that can be more successful, and which may have higher revenues per hectare. Currently, the use of productive diversification systems has been successfully used within the same area, with two or more production systems being explored, improving the perspective of generating economic return to the producer.

The crop-livestock-forest integration system (ICLF) is a form of diversified production, developing various activities and crops within the same area in the farm, to maximize profit and reduce risks. ICLF can provide considerable increases in the production of meat, wood and grains in the same area (Pacheco et al., 2015). In addition to being economically viable (Muniz et al., 2007b), it also reduces the risks for the producer (Muniz et al., 2007a).

The ICLF is one of these diversification strategies. It represents a production technology that integrates agricultural, livestock and forestry production systems, in a spatial and/or temporal dimension, seeking synergic effects between the components of the agroecosystem for the sustainability of the farm. Considering its environmental suitability, the valuation of human and natural capital and the economic viability of the production system (Balbino et al., 2011). 
The potential economic benefits of these integrated systems can be reflected in economies of scope (cost reduction due to the production of multiple products) or diversification risk reduction effects. In addition, they may involve lower production variability and higher yields (Cordeiro et al., 2015).

Degraded areas and/or with low yields can be recovered with the adoption of integrated forest farming (ICLF), which, in turn, consists of the implantation of different production systems of grains, fibers, meat, milk, agroenergy, among others, In the same area, in intercropping, sequential or rotational planting, taking advantage of the synergism existing between them, thus having a greater productive benefit and in the protection and conservation of the environment (Alvarenga et al., 2006).

For the recovery of degraded pastures one of its constraints is its prohibitive cost of renovation, with the adoption of the ICLF, using the consortium of two grasses, it can meet the objectives of providing feed for the cattle ranch, in the period between the end of summer until the beginning of spring, and provide income from the sale of grains, reducing expenses (Tavares, 2012).

To minimize the cost of pasture reform, ICLF has been shown to be a viable alternative for the conditions in Maranhão state (Brazil), defining a sustainable production strategy that integrates agricultural and livestock activities, carried out in the same area, in intercropping, with synergistic effects among the components of the pasture (Kluthcouski et al., 2003). In addition, it is relevant to highlight the importance of the economic viability of agriculture.

Corn (Zea mays L.) stands out in the context of ICLF due to the countless applications that this cereal has on the farm, whether in animal feed in form of grains or in green or silage, in human nutrition or in the generation of revenue through the marketing of surplus production (Alvarenga et al., 2006).

According to Borges (2011), the use of corn crop in the ICLF system is feasible and advisable, bringing a greater diversification of income. It is particularly interesting to use the corn crop for the formation of intercropping systems due to the simplicity of its conduction and its range of use in the face of climatic diversities (Macedo et al., 2006).

The implementation of the ICLF system in farms has benefited its components, often increasing yields and profitability within the same area compared to conventional systems, making it a strategy to be adopted. In addition to being a system that can be deployed in most farms considering local resources as well as the needs of producers. Thus, the ICLF system aims to change the land use system, based on the integration of the components of the production system, aiming to achieve higher levels of product quality, environmental quality and competitiveness (Sandini, 2011).

However, before choosing to invest in any production system, it is necessary to analyze its economic viability and its risk. This is a set of information of a quantitative and qualitative nature that allows to estimate the scenario based on a chosen alternative (Kassai et al., 2005). In this context, the objective of this study was to estimate the cost of production and the profitability of corn cultivation, in the short term, in the implementation of the ICLF system for pasture recovery in the municipality of Pindaré-Mirim, of Maranhão (MA, Brazil), using the consortium with eucalyptus and a forage species.

\section{Materials and Methods}

The study was developed at the Technological Reference Unit (TRU) for the ICLF of Embrapa Cocais, located in the municipality of Pindaré-Mirim/MA (Brazil), Micro-region of Pindaré, at latitude coordinates $3^{\circ} 46^{\prime} 13.60^{\prime \prime}$ S, longitude $45^{\circ} 29^{\prime} 42.00^{\prime \prime} \mathrm{W}$, and with altitude of 28 meters above sea level. According to the classification of Koeppen (1948), the local climate is AW type (hot and humid), with an average annual temperature of $26.0^{\circ} \mathrm{C}$ and average annual rainfall ranging from 1,600 to 2,000 $\mathrm{mm}$ (Geplan, 2002).

The soil class of the farm where the experiment was installed is classified as Hapless Plinth. In relation to its relief, this one has variations of soft-waved to waved, being covered originally by vegetation of tropical forest subperenifolia dabótilo-palmácea babaçual, dominant in the Mid-North region of the State of Maranhão (Maranhão, 2003).

In the experimental area, a soil analysis was carried out, followed by the delimitation of the treatments to be implemented. The recommendations applied regarding fertilization were according to the result of the soil analysis (Table 1). According to the results of the soil analysis, liming was not necessary. 
Table 1. Results of the soil analysis performed in the experiment implementation area, municipality of Pindaré-Mirim/MA, Brazil

\begin{tabular}{|c|c|c|c|c|c|c|c|c|c|c|c|}
\hline Depth & Organic matter & $\mathrm{pH}$ & $\mathrm{P}$ & $\mathrm{K}$ & $\mathrm{Ca}$ & $\mathrm{Mg}$ & $\mathrm{H}+\mathrm{AL}$ & $\mathrm{Na}$ & $\mathrm{Al}$ & $\mathrm{H}$ & $\mathrm{C}$ \\
\hline -- cm -- & $--\mathrm{g} / \mathrm{dm}^{3}--$ & -- $\mathrm{CaCl}_{2}--$ & -- $\mathrm{mg} / \mathrm{dm}^{3}--$ & --- & ----- & - & $\mathrm{nmolc} / \mathrm{dm}$ & 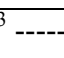 & & $---\cdot$ & $--\mathrm{g} / \mathrm{dm}^{3}--$ \\
\hline $0-20$ & 11 & 4.6 & 2 & 4.4 & 32 & 13 & 23 & 7.4 & 0 & 23 & 6.1 \\
\hline
\end{tabular}

Source: Research results.

The application of the herbicide Glyphosate desiccant at the dosage of $5 \mathrm{~L} \mathrm{ha}^{-1}$, was carried out to prepare the area and implantation of the ICLF. After the emergence of corn, the application of the post-emergent herbicides was made, Atrazine and Kyron, with dosages of 3.0 and $0.5 \mathrm{~L} \mathrm{ha}^{-1}$, respectively, for the initial grazing control.

Planting of corn and grass seeds was carried out with the aid of a no-tillage seeder-fertilizer with separate compartment for the distribution of grass seeds. For fertilization of planting, $400 \mathrm{~kg} \mathrm{ha}^{-1}$ of the formulated fertilizer NPK 04-30-10 + 0.5\% of Zn was used, being its distribution in furrows with a depth of $5 \mathrm{~cm}$ and next to the corn seeds. After 10 days of corn germination, the first fertilization was performed with $160 \mathrm{~kg} \mathrm{ha}^{-1}$ of urea and $100 \mathrm{~kg} \mathrm{ha}^{-1}$ of potassium chloride, and the fertilizer was applied with the aid of a fertilizer in the furrows between the lines of corn. The second cover fertilization occurred 10 days after the first one with $160 \mathrm{~kg} \mathrm{ha}^{-1}$ of urea and $100 \mathrm{~kg} \mathrm{ha}^{-1}$ of potassium chloride, adopting the same procedure as the first fertilization.

A simple hybrid corn (KWS 9304) with spacing of $0.60 \mathrm{~m}$ between rows and $0.25 \mathrm{~m}$ between plants (population of 66 thousand plants $\mathrm{ha}^{-1}$ ) was used. For the pasture formation, seeds of Urochloa brizantha cv. Marandu. Eucalyptus (Eucalyptus urograndis) was used for the implanted arboreal component, following an arrangement with $28 \times 3 \times 2 \mathrm{~m}$ double rows, where $28 \mathrm{~m}$ corresponded to the distance between the double rows, $3 \mathrm{~m}$ between rows in the row and $2 \mathrm{~m}$ spacing between plants in the line.

Data was obtained from the agricultural year 2015/2016. The management of the integration system was carried out following the "Santa Fe" model (Kluthcouski et al., 2000), this type of management aims at the recovery of areas in a situation of mild or moderate degradation, which the soil still has productive capacity and it is necessary to carry out an adequate management to improve the structuring and conservation of the same. In this management, corn intercropped with pasture was planted. Corn intercropping was carried out in accordance with the recommendations of EMBRAPA (2015).

The costing methodology used was the TOC of production, according to Matsunaga et al. (1976) and Montes et al. (2006), which is made up of the sum of direct expenses of costing: performed operations, inputs (fertilizers, seeds, pesticides write the other inputs), labor and machinery, called effective operational cost (EOC). For indirect expenses, such as depreciation, social and financial charges, were considered a $5 \%$ of the EOC (Matsunaga et al., 1976; Barbosa et al., 2014), being considered this percentage due to the accomplishment of the study occur in experimental areas. With the sum of EOC and indirect costs, the TOC was obtained, which were extrapolated per hectare.

For economic analysis of corn production, three different prices were considered: (A) the price received by the producer in the 2015/2016 harvest, being the sale done by producer himself, where the buyers went to look for to the producer due to the lack of offer of the producer to the region; (B) the historical average of the last 30 months to the date of actual sale of the product; and (C) the minimum guarantee price of the federal government in force during the 2015/2016 harvest period. For the study, the economic evaluation to be carried out based on these three types of prices, which are mechanisms for planning possible revenue to be obtained by the producer, was used based on the real perspectives made available by government agencies (CONAB, 2016), serving as the basis for the producer of the prices that will be practiced for the agricultural year and for the history of the years.

The indicators defined by Martin et al. (1998):

a) Gross Revenue (GR): production per hectare multiplied to a pre-defined or effectively received sales price, i.e., $\mathrm{GR}=$ Prod $\times$ Pr, where, Prod = production per unit area and $\mathrm{Pr}=$ product price;

b) Gross Margin (GM): margin, in relation to the EOC, that is, the result that remains after the producer has paid the actual operating cost and in relation to the same cost (in percentage) considering a given unit price of sales and the yield of the production system for the activity, i.e. $\mathrm{GM}=((\mathrm{GR}-\mathrm{EOC}) / \mathrm{EOC}) \times 100$;

c) Operational Profit (OP): difference between gross revenue and total operating cost per hectare, that is, $\mathrm{OP}=$ GR - TOC; 
d) Profitability Index (PI): ratio between operating income and gross revenue, in percent, where, $\mathrm{PI}=(\mathrm{OP} / \mathrm{GR})$ $\times 100$; and

e) Leveling Point (LP): is a relation of costs, between total operation cost and the product price unit, where, $\mathrm{LP}=\mathrm{TOC} / \mathrm{Pr}$.

In the present study we adopted the concept described by Robson (1996), of a case study. The established economic coefficients were extrapolated to real field conditions values, according to the practices usually performed by regional producers, and the values obtained per hectare were demonstrated. Also, since the research was carried out in a demonstrative area, the items related to the fixed costs of the activity, such as land remuneration, pro-labor of the producer, and interest on facilities, improvements, machinery and equipment, were not considered.

\section{Results and Discussion}

The total and actual operating costs recorded in the experiment were estimated at one hectare, and the TOC of US\$ 1,672.72 per hectare was found. This amount corresponded to the sum of the EOC plus the overhead. Regarding EOC, which represents all the monetary disbursements made by the producer, this totaled US\$ $1,593.06 \mathrm{ha}^{-1}$, representing $95.24 \%$ of total costs (Table 2).

Table 2. Operating cost statement for 1 hectare of corn crop in the ICLF system for the agricultural year 2015/2016, in the municipality of Pindaré-Mirim, MA, Brazil

\begin{tabular}{|c|c|c|c|c|c|}
\hline DESCRIPTION & UNIT & AMOUNT & P.UNIT (US\$) & P.TOTAL (US\$) & PART. \\
\hline Desiccant herbicide (Glyphosate) & $\mathrm{L} / \mathrm{ha}$ & 5.0 & 5.94 & 29.71 & $1.78 \%$ \\
\hline Herbicide 1 (Atrazine) & $\mathrm{L} / \mathrm{ha}$ & 3.0 & 4.82 & 14.46 & $0.86 \%$ \\
\hline Herbicide 2 (Kyron) & $\mathrm{L} / \mathrm{ha}$ & 0.5 & 14.13 & 7.07 & $0.42 \%$ \\
\hline Fungicide 1 (Manzate) & $\mathrm{L} / \mathrm{ha}$ & 3.0 & 13.49 & 40.48 & $2.42 \%$ \\
\hline Insecticide 1 (Agritoato) & $\mathrm{L} / \mathrm{ha}$ & 3.0 & 15.42 & 46.26 & $2.77 \%$ \\
\hline Insecticide 2 (Lanate) & $\mathrm{L} / \mathrm{ha}$ & 3.0 & 15.42 & 46.26 & $2.77 \%$ \\
\hline Treatment of seedlings & $\mathrm{L}$ & 0.3 & 30.84 & 8.81 & $0.53 \%$ \\
\hline Pesticides & & & & 193.04 & $11.54 \%$ \\
\hline Cover fertilizer (Urea) & Bags & 2.3 & 38.74 & 88.55 & $5.29 \%$ \\
\hline Cover fertilizer (Potassium chloride) & Bags & 4.6 & 40.80 & 186.50 & $11.15 \%$ \\
\hline Preplant fertilization $(04-30-10+\mathrm{Zn})$ & Ton & 0.4 & 527.36 & 226.01 & $13.51 \%$ \\
\hline Preplant fertilization for eucalyptus (04-30-10) & Bags & 0.9 & 47.22 & 40.48 & $2.42 \%$ \\
\hline Fertilizers & & & & 541.54 & $32.37 \%$ \\
\hline Corn seed (KWS 9304) & Bags & 1.1 & 112.58 & 128.66 & $7.69 \%$ \\
\hline Pasture Seed (Marandú) & Bags & 0.6 & 127.18 & 72.68 & $4.34 \%$ \\
\hline Eucalyptus seedlings & Unit & 257.1 & 0.24 & 61.95 & $3.70 \%$ \\
\hline Seeds and seedlings & & & & 263.29 & $15.74 \%$ \\
\hline Manual application of agrochemical & Contract work & 1.0 & 32.12 & 32.12 & $1.92 \%$ \\
\hline Eucalyptus plantation labor force & Daily & 1.7 & 12.85 & 22.03 & $1.32 \%$ \\
\hline Technical assistance of eucalyptus plantation & Daily & 1.0 & 13.77 & 13.77 & $0.82 \%$ \\
\hline Manual application of cover fertilizer & Contract work & 2.0 & 32.12 & 64.25 & $3.84 \%$ \\
\hline Manual application of pesticides & Contract work & 3.0 & 32.12 & 96.37 & $5.76 \%$ \\
\hline Harvest labor & Daily & 14.6 & 12.85 & 187.23 & $11.19 \%$ \\
\hline General labor force & & & & 415.77 & $24.86 \%$ \\
\hline Seed drill & $\mathrm{MH}$ & 2.9 & 48.19 & 137.67 & $8.23 \%$ \\
\hline Thresher-machine & MH & 1.0 & 41.76 & 41.76 & $2.50 \%$ \\
\hline Machinery and operations & & & & 179.43 & $10.73 \%$ \\
\hline Indirect expenses & & & & 79.65 & $4.76 \%$ \\
\hline Effective Operational Cost (EOC) & & & & $1,593.06$ & $95.24 \%$ \\
\hline Total Operating Cost (TOC) & & & & $1,672.72$ & $100 \%$ \\
\hline
\end{tabular}

Note. $\mathrm{MH}=$ Machine hour; Und = unit; Daily; Daily = Service performed during 8 hours of work; Contract work $=$ Specific service activity by area; $\mathrm{L} / \mathrm{Ha}=$ Liters per hectare.

Source: Research results. 
Fertilizer expenses amounted to US\$ $541.54 \mathrm{ha}^{-1}$, with a $32.37 \%$ participation in the TOC. The lack of specialized companies for the sale of inputs in the region, being necessary for the acquisition in distant regions of the productive area, was one of the reasons for this high cost. Fertilizers carried out followed the recommendations for the cultivation of hybrid corn, which has high productive performance and higher nutrient requirement, accentuating the cost with fertilizer acquisition.

The second largest cost was labor, which had an expense of US\$ $415.77 \mathrm{ha}^{-1}$, with a $24.86 \%$ share of the TOC. The high cost in this case is due to the fact that the region where the experiment was developed is considered an area of extensive livestock production. This contributed to the lack of specific machinery for the development of the agricultural activity, and the machinery rent is unfeasible in the region. For the accomplishment of the work, it was necessary the hiring of workers for manual activities, which promoted an increase in the cost of production.

Expenditures on seeds and seedlings totaled US\$ $263.29 \mathrm{ha}^{-1}$, with a participation of $15.74 \%$ in TOC. The need to acquire certified and quality material is a preventive cost, therefore there was no savings in the acquisition of these materials, mainly because they are essential for a performance and establishment of the ICLF system with high productivity of the components according to their potential genetic.

The costs of pesticides were US\$ $193.04 \mathrm{ha}^{-1}$, with an $11.54 \%$ share of the TOC. The expenditures with these inputs were made depending on the need to manage the corn crop and other components of the ICLF system, in which grass growth control was necessary, in this case Atrazine and Kyron, so that pasture would not compete with corn at the most susceptible time. In addition to the preventive use against pests and diseases for both the agricultural crop and the forest component we use Atrazine and Kyron.

The cost of machinery and operations, had a value of US\$ $179.43 \mathrm{ha}^{-1}$, using a $10.73 \%$ of the TOC. As the region did not have specific machines for grain crops, the use of these implements was small, with only one-off operations, such as planting with sowing machine and the use of combine harvester.

The gross revenue achieved in relation to the price received by the producer in the 2015/2016 harvest and the historical average of the last 30 years to the actual sale date was sufficient to cover the TOC, only in relation to the minimum price the producer could not pay his costs operations (Table 3).

Table 3. Deflated prices, productivity and profitability indicators of corn grown in the ICLF system in the city of Pindaré-Mirim, Brazil, Brazil, 2016

\begin{tabular}{|c|c|c|c|}
\hline Price of the $60 \mathrm{~kg}$ bag (US\$) & US\$ $19.27^{1}$ & US\$ $11.69^{2}$ & US\$ 8.03 ${ }^{3}$ \\
\hline Productivity (bags/ha) & 159 & 159 & 159 \\
\hline Gross revenue & US\$ $3,064.57 \mathrm{ha}^{-1}$ & US\$ $1,858.44 \mathrm{ha}^{-1}$ & US\$ $1,276.39 \mathrm{ha}^{-1}$ \\
\hline Gross Margin & $92 \%$ & $17 \%$ & $-20 \%$ \\
\hline Net Margin & US\$ $1,391.85 \mathrm{ha}^{-1}$ & US\$ $185.72 \mathrm{ha}^{-1}$ & US\$ -396.33 ha-1 \\
\hline Profitability Index & $45 \%$ & $10 \%$ & $-31 \%$ \\
\hline Leveling point & 87 & 143 & 208 \\
\hline
\end{tabular}

Note. ${ }^{1}$ Average price received by the producer at the time of sale, June $2016 ;{ }^{2}$ Average price for last 30 months;

${ }^{3}$ Minimum Price Guarantee.

Source: Research results.

In relation to productivity, an average yield of 159 sacks per hectare, $9,540 \mathrm{~kg} \mathrm{ha}^{-1}$, was obtained, comparing CONAB (2016) estimate for the harvest of 2015/2016 and the June survey, the month in which the harvest occurred, the value found was 3.5 times higher than the average for the state, $2,666 \mathrm{~kg} \mathrm{ha}^{-1}$, and 1.9 times higher than the Brazilian average, $4,797 \mathrm{~kg} \mathrm{ha}^{-1}$.

The results found for the gross margin, considering the price received by the producer at the time of sale and the historical average, there was a better remuneration on the investment in the corn crop and the payment of the costs. Regarding the minimum price, if the producer opts for this type of remuneration, he should reduce his production costs. Otherwise, for the conditions of this study, he will be investing in an activity that will cause him loss.

Ensuring broad access to these factors of production is a necessary strategy to ensure attractiveness to ICLF. High productivity increases the demand for modern inputs and capital goods. The crop-livestock integration can 
have a favorable effect on the reduction of production and price risk by the diversification of activities. However, the high capital demand of these systems increases the financial risk of the enterprise (Martha Junior et al., 2011).

The net margin, also known as profit, for the price received by the producer at the time of sale and the historical average, obtained an economic return per hectare very favorable to its implantation, being the minimum price the only one that does not give profit. In addition to obtaining profits per hectare, the sales companies paid the costs of the recovery and/or formation of the pasture and the forest, which could be a complementary income in the off-season.

Regarding the profitability index, it was attractive to invest with corn in an ICLF system when the sale of the bags occurred using the price received by the producer at the time of sale and the historical average, with a return of $45 \%$ to $10 \%$. The only case in which the producer did not have profitability is sold according to the minimum price.

In relation to the leveling point, the minimum quantity to be produced for the activity to be non-detrimental, had value obtained from bags per hectare sufficient to pay the productive costs using the price received by the producer at the time of sale and the historical average. However, when it was sold over the minimum price, the quantity produced was not enough to cover costs.

The economic efficiency indicators presented promising values of profit, demonstrating that in this study with corn production in the 1st year it would be possible, besides the payment of the ICLF system implementation, as an alternative for the recovery of degraded pasture, a short-term income for the producer.

\section{Conclusion}

The use of the corn crop in the ICLF system is an economically viable alternative for the Pindaré-Mirim region, when the product was sold taking into account the price at the time of sale and the price of the history of the last 30 years is and it is recommended to use this technology for the region, since it can pay the costs of recovering a degraded pasture and still obtain an economic return from the sale of corn bags.

\section{Acknowledgements}

The authors thank to the Foundation for Supporting Research and Scientific and Technological Development of Maranhão (FAPEMA) for funding the Project, through the Universal Call for Research Support 14/2015. In addition, we thank for the provision of scientific initiation grants during the years of project development.

We also thank to the Brazilian Agricultural Research Corporation (EMBRAPA), for the technical and operational contribution during the research development.

\section{References}

Alvarenga, R. C., Cobucci, T., Kluthcouski, J., Wruck, F. J., Cruz, J. C., \& Neto, M. M. G. A. (2006). A cultura do milho na integração lavoura-pecuária. Informe Agropecuário, 27(233), 106-126.

Balbino, L. C., Barcellos, A. O., \& Stone, L. F. (Eds.). (2011). Marco referencial: Integração Lavoura-Pecuária-Floresta (p. 130). Brasília, DF: Embrapa.

Barbosa, R. M., Homem, B. F. M., \& Tarsitano, M. A. A. (2014). Custo de produção e lucratividade da cultura do amendoim no município de Jaboticabal, São Paulo. Rev. Ceres, 61(4), 475-481. https://doi.org/10.1590/ 0034-737X201461040005

Borges, W. L. B. (2011). Produção de milho em sistema de integração na região noroeste paulista. Pesquisa \& Tecnologia Apta Regional, 8(2), 6-12.

CONAB (Companhia Nacional de Abastecimento). (2016). Acomp. safra bras. Grãos (pp. 1-174, v. 9 Safra 2015/16). Nono Levantamento, Brasília.

Cordeiro, L. A. M., Vilela, L., Marchão, R. L., Kluthcouski, J., \& Martha Junior, G. B. (2015). Integrated Crop-Livestock And Integrated Crop-Livestock-Forest Systems: Strategies For Sustainable Intensification Of Soil Use. Cadernos de Ciência \& Tecnologia, 32(1/2), 15-53.

EMBRAPA (Empresa Brasileira de Pesquisa Agropecuária). (2015). Embrapa Milho e Sorgo. Sistema de produção, $1.9^{\mathrm{a}}$ edição. Nov.

GEAGRO. (2003). Zoneamento Costeiro do Estado do Maranhão. Gerência de Estado de Agricultura, Pecuária e Desenvolvimento Rural (p. 253). GEAGRO, Fundação Sousândrade, Universidade Federal do Maranhão e Universidade Estadual do Maranhão. Maranhão, Brazil. 
GEPLAN (Gerência de Planejamento e Desenvolvimento Econômico). (2002). Atlas do Maranhão (p. 44). São Luís: UEMA/GEPLAN.

Kassai, J. R. et al. (2005). Retorno de Investimento: Abordagem matemática e contábil do Lucro Empresarial (Atlas 3rd ed., p. 273). São Paulo.

Kluthcouski, J., Cobucci, T., Aidar, H., Yokoyama, L. P., Oliveira, I. P., Costa, J. L. S., ... Magnabosco, C. U. (2000). Sistema Santa Fé - tecnologia Embrapa: Integração lavoura-Pecuária pelo consórcio de culturas anuais com forrageiras, em áreas de lavoura, nos sistemas direto e convencional (Circular Técnica, 38, p. 28). Santo Antônio de Goiás, Embrapa Arroz e Feijão.

Kluthcouski, J., Yokoyama, L. P., \& Stone, L. F. (2003). Fazendas de referência na integração lavoura-pecuária. In J. Kluthcouski, L. F. Stone, \& H. Aidar (Eds.), Integração lavoura-pecuária (pp. 535-554). Santo Antônio de Goiás: Embrapa Arroz e feijão.

Macedo, R. L. G., Bezerra, R. G., Venturin, N., Vale, R. S. do, \& Oliveira, T. K. de. (2006). Silvicultural performance of eucalyptus clones and agronomic characteristic of corn planted in agroforestry systems. Revista Árvore, 30(5), 701-709. https://doi.org/10.1590/S0100-67622006000500003

Martha Junior, G. B., Alves, E., \& Contini, E. (2011). Economic dimension of integrated crop-livestock systems. Pesq. Agropec. Bras., 46(10), 1117-1126. https://doi.org/10.1590/S0100-204X2011001000002

Martin, N. B., Serra, R., Oliveira, M. D. M., Ângelo, J. A., \& Okawa, H. (1998). Sistema integrado de custos agropecuários: Custagri. Informações Econômicas, 28(1), 7-28.

Matsunaga, M., Bemelmans, P. F., Toledo, P. D., Dulley, R. D., Okawa, H., \& PedrosO, I. A. (1976). Metodologia de custo de produção utilizada pelo IEA. Agricultura em São Paulo, 23(1), 123-139.

Montes, S. M. N. M., Firetti, R., Golla, A. R., * Tarsitano, M. A. A. (2006). Custos e rentabilidade da batata-doce (Ipomoea batatas L.) na região oeste do Estado de São Paulo: Estudo de caso. Informações Econômicas, 36(4), 15-23.

Muniz, L. C., Figueiredo, R. S., \& Magnabosco, C. D. U., Wander, A. E., \& Martha Júnior, G. B. (2007b). Análise econômica da integração lavoura e pecuária com a utilização do system dynamics. 45th Congresso da Sociedade Brasileira de Economia, Administração e Sociologia Rural, Londrina.

Muniz, L. C., Figueiredo, R. S., Magnabosco, C. de U., Wander, A. E., \& Martha Júnior, G. B. (2007a). Análise de risco da integração lavoura e pecuária com a utilização do system dynamics. 45th Congresso da Sociedade Brasileira de Economia, Administração e Sociologia Rural, Londrina.

Pacheco, A. R., Nicoli, C. M. L., Reis, C. F., Monteiro, L. A., \& Wander, A. E. (2015). Adoption of crop-livestock-forest systems: What comes next? Proceedings of World Congress on Crop-Livestock-Forest Integrated Systems, Brasilia. Brasília: Embrapa.

Robson, C. (1996). Real word research (p. 510). Oxford: Blackwell.

Sandini, I. E., Moraes, A., Pelissari, A., Neumann, M., Falbo, M. K., \& Novakowiski, J. H. (2011). Residual effect of nitrogen in the maize production in crop livestock integration. Ciencia Rural, Santa Maria, 41(8), 1315-1322. https://doi.org/10.1590/S0103-84782011005000099.

Tavares, S. (2012). Reforma de Pastagem Através da Integração Entre Lavoura e Pecuária. Pesquisa \& Tecnologia, 9(2).

\section{Copyrights}

Copyright for this article is retained by the author(s), with first publication rights granted to the journal.

This is an open-access article distributed under the terms and conditions of the Creative Commons Attribution license (http://creativecommons.org/licenses/by/4.0/). 